\title{
METODE ELEMEN HINGGA UNTUK PENYELESAIAN PERSAMAAN SCHRÖDINGER ATOM HIDROGENIK
}

\author{
Paken Pandiangan (pakenp@mail.ut.ac.id) \\ Universitas Terbuka \\ Supriyadi (adyph_0901@yahoo.com) \\ A. Arkundato (a_arkundato@yahoo.com) \\ Universitas Jember
}

\begin{abstract}
The research computed the energy levels and radial wave functions of the Hydrogen Atom. The method used for computation was FEM (finite element method). Using the variational method approach, FEM was applied to the action integral of Schrödinger equation. This lead to the eigenvalue equation in the form of global matrix equation. The results of computation were depended on boundary of the action integral of Schrödinger equation and number of elements. For boundary $0-100 a_{0}$ and 100 elements, they were the realistic and best choice of computation to the closed analytic results. The computation of first five energy levels resulted $E_{1}=-0.99917211 R_{\infty}, E_{2}=-0.24984445 R_{\infty}, E_{3}=-0.11105532 R_{\infty}$, $E_{4}=-0.06247405 R_{\infty}$ and $E_{5}=-0.03998598 R_{\infty}$ where $1 R_{\infty}=13.6 \mathrm{eV}$. They had relative error under $0.1 \%$ to the analytic results.
\end{abstract}

Key words: FEM, Hydrogen atom, Schrödinger equation.

Telaah mikroskopis atom hidrogen dengan menggunakan persamaan Schrödinger sejauh ini telah dikerjakan dengan baik secara analitik (Nikishkov, 2004). Untuk atom multi elektron, maka solusi analitik yang diinginkan sebagai pemecahan persamaan Schrödingernya menjadi makin rumit diperoleh dan memerlukan aproksimasi lebih lanjut. Salah satu aproksimasi yang dapat diadopsi adalah mencari solusi numerik menggunakan metode numerik yang ada. Metode numerik pemecahan persamaan diferensial (misalnya persamaan Schrödinger) yang umum digunakan adalah metode finite difference (FD). Metode numerik yang lain adalah metode elemen hingga (finite element methods, FEM) yang saat ini mulai banyak dieksplorasi dan berkembang cepat untuk diterapkan pada problem-problem fisika. Salah satu kelebihan FEM adalah dapat diterapkan untuk problem fisis dimana bentuk potensialnya (dalam persamaan Schrödinger) sangat kompleks dan kurang simetris (Brugioni, 1995). Pada riset yang kami lakukan, sebagai riset pendahuluan, kami mencoba menggunakan metode FEM ini untuk atom hidrogen yaitu menghitung tingkat-tingkat energinya secara first principle, yaitu memecahkan persamaan Schrödinger untuk atom hidrogen. Hasil numerik yang diperoleh kemudian dibandingkan dengan hasil analitik yang sudah ada. 


\section{Solusi Analitik Persamaan Schrödinger Atom Hidrogen}

Persamaan Schrödinger bebas waktu untuk atom Hidrogen dimana potensialnya dinyatakan dalam satuan CGS adalah

$$
-\frac{\hbar^{2}}{2 m_{e}} \nabla^{2} \psi(\vec{r})-\frac{e^{2}}{r} \psi(\vec{r})=E \psi(\vec{r})
$$

Dalam sistem koordinat bola, persamaan diatas dapat dinyatakan dengan

$\left\{-\frac{\hbar^{2}}{2 m_{e}}\left[\frac{1}{r^{2}} \frac{\partial}{\partial r}\left(r^{2} \frac{\partial}{\partial r}\right)+\frac{1}{r^{2} \sin \theta} \frac{\partial}{\partial \theta}\left(\sin \theta \frac{\partial}{\partial \theta}\right)-\frac{1}{r^{2} \sin ^{2} \theta} \frac{\partial}{\partial \varphi}\right]-\frac{e^{2}}{r}\right\} \psi(r, \theta, \varphi)=E \psi(r, \theta, \varphi)$

Penyelesaian lengkap secara analitik secara panjang lebar telah banyak dibahas dalam buku teks (Mohan, 2002), yang menghasilkan solusi untuk atom hidrogen adalah:

$$
E_{n}=-\frac{e^{2}}{2 a_{0} n^{2}} \cong-\frac{13,6}{n^{2}} e V \quad n=1,2,3, \ldots
$$

\section{Integral Aksi}

Dinamika sistem fisis, baik klasik maupun kuantum sebenarnya mengikuti rumusan persamaan diferensial yang dapat diturunkan dari prinsip aksi stasioner yang bersifat umum. Dalam hal ini, Euler dan Lagrange telah memberikan suatu framework untuk merealisasikan prinsip ini dalam memecahkan problem fisika. Di dalam mekanika klasik, maka azas aksi stasioner menyatakan untuk sistem konservatif integral berikut

$$
\Lambda=\int_{t_{a}}^{t_{b}} L(\bar{q}, \bar{q}, t) d t
$$

bersifat stasioner (Brugioni, 1995). L adalah Langrangian dan variabel $\Lambda$ disebut dengan integral aksi atau singkatnya disebut aksi. Berdasarkan syarat batas $(\mathrm{BC}=$ Boundary Conditions) integral aksi $\Lambda$ diambil pada nilai ektremum menurut syarat

$$
\delta \Lambda=0
$$

Evaluasi integral aksi sangat membantu kita dalam mengkaji dinamika sistem kuantum, dalam hal ini persamaan Schrödinger, dengan menggunakan FEM.

\section{Metode Elemen Hingga (FEM)}

Konsep dasar yang melandasi FEM adalah prinsip diskritisasi. Secara umum, diskritisasi dapat diartikan sebagai upaya untuk membagi sistem dari problem yang akan diselesaikan (obyek) menjadi bagian-bagian yang lebih kecil. Bagian-bagian yang lebih kecil tersebut selanjutnya disebut sebagai elemen hingga. Diskritisasi ini muncul karena adanya kesulitan untuk mempelajari sistem secara keseluruhan.

Pendekatan yang sering digunakan untuk merumuskan suatu problem fisis ke dalam analogi diskritisasi FEM yaitu metode Galerkin dan metode variasi (Gasiorowicz, 1995). Perumusan FEM dengan menggunakan metode Galerkin didasarkan pada minimasi residu (sisa) yang tertinggal setelah suatu solusi pendekatan disubsitusikan ke dalam persamaan diferensial dari suatu problem fisis. Sedangkan metode variasi didasarkan pada nilai-nilai stasioner dari suatu fungsi atau besaran skalar yang berkaitan dengan suatu problem fisis untuk mendapatkan solusinya (Thankappan, 1985). 
Perumusan FEM dalam penelitian ini dipilih pendekatan metode variasi dengan menggunakan integral aksi yang diperoleh dari prinsip aksi stasioner. Dengan pendekatan ini, perumusan FEM berangkat dari definisi integral fungsi. Misalkan kita mempunyai fungsi $f(x)$ yang akan diintegralkan dalam selang dari $x_{a}, x_{b}$. Dengan metode trapezium kita dapat menghitung integral tertentu ini dalam bentuk jumlahan dari elemen-elemen luas secara keseluruhan, seperti pada gambar (1a). Elemen-elemen luas diaproksimasi dengan sebuah konstanta atau lebih umum sebuah polinomial (Gasiorowicz, 1995).

Untuk problem fisis satu dimensi dalam daerah $\left[x_{\min }, x_{\operatorname{mak}}\right]$ maka perhitungan integral aksi dapat dilakukan dalam bentuk diskritisasi region. Daerah integrasi dibagi menjadi elemen-elemen yang lebih kecil yang disebut elemen-elemen hingga, seperti pada gambar (1b). Integral aksi merupakan jumlahan integral-integral aksi itu sendiri pada masing-masing elemen sehingga dapat dituliskan menjadi

$$
\Lambda=\sum_{(i e l)}^{\text {nelem }} \Lambda^{(i e l)}
$$

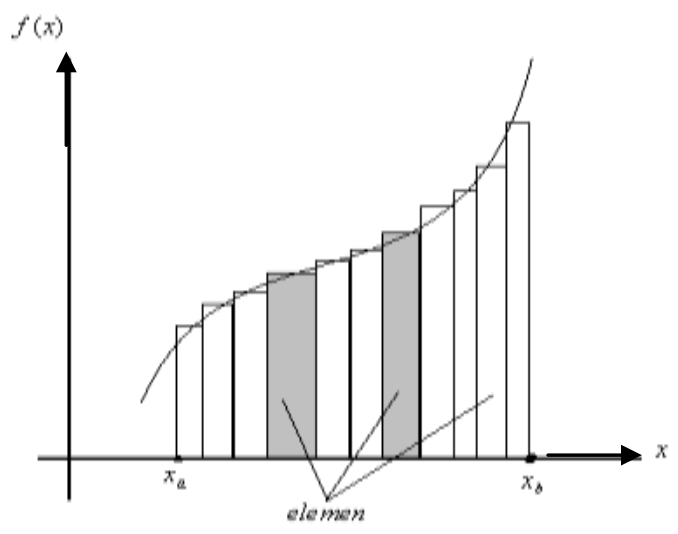

(a)

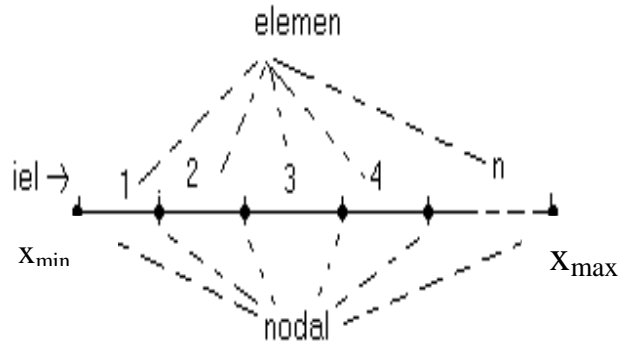

(b)

Gambar 1. (a) Integral $f(x)$ merupakan jumlahan elemen-elemen luas di bawah kurva (b) Daerah diskretisasi

Penerapan azas variasi nodal yaitu dengan memvariasikan integral aksi terhadap variabel nodal misalkan $\psi_{a}{ }^{*}$, maka didapatkan persamaan simultan untuk koefisien $\psi_{\beta}$ yang belum diketahui

$$
\frac{\delta \Lambda}{\delta \Psi_{\alpha} *}=\sum_{\beta} M_{\alpha \beta} \Psi_{\beta}=0
$$

Beberapa koefisien $\psi_{\beta}$ diketahui dari syarat batas $(\mathrm{BC})$ dan dimasukkan ke dalam persamaan simultan ini. Koefisien-koefisien yang lainnya dapat diperoleh dengan metode matriks standar setelah nilai batas diterapkan untuk koefisien yang bersangkutan (Gasiorowicz, 1995).

\section{METODOLOGI PENELITIAN}

Penelitian yang dilakukan ini adalah penelitian dalam bidang fisika teori-komputasi. Metode yang digunakan untuk mendapatkan eigen nilai atom hidrogen dalam penelitian ini adalah 
pendekatan numerik (numerical approach) dengan menggunakan metode elemen hingga (finite element method, FEM).

Dengan menggunakan kesalahan relatif, hasil numerik berupa eigen energi atom hidrogen dibandingkan terhadap hasil analitik.

$$
\text { kesalahan relatif }=\left|\frac{E_{N}-E_{T}}{E_{T}}\right| \times 100 \%
$$

$E_{N}$ mewakili tingkat-tingkat energi atom hidrogen secara numerik sedangkan $E_{T}$ mewakili tingkat-tingkat energi atom hidrogen secara analitik. Eigen energi atom hidrogen dikatakan akurat jika kesalahan relatifnya kurang dari $1 \%$. Sedangkan analisis terhadap fungsi gelombang radial dilakukan secara kualitatif melalui visualisasi grafik. Hasil perhitungan numerik fungsi gelombang radial atom hidrogen mempunyai kesesuaian yang baik jika simpangan terhadap hasil analitiknya cukup kecil.

\section{HASIL DAN PEMBAHASAN}

\section{Perumusan Metode Elemen Hingga Untuk Problem Atom Hidrogen Bagian Radial}

Dengan mengambil bagian radial dari persamaan (2) dengan batasan untuk keadaan $n s$, maka dapat dituliskan

$$
\left\{-\frac{\hbar^{2}}{2 m_{e}}\left[\frac{1}{r^{2}} \frac{d}{d r}\left(r^{2} \frac{d}{d r}\right)\right]-\frac{e^{2}}{r}\right\} \psi(r)=E \psi(r)
$$

Untuk tujuan komputasi masalah atomik, persamaan di atas dapat dituliskan kembali dalam satuan yang lebih sesuai yaitu jari-jari Bohr $a_{0}$ sebagai satuan panjang dan Rydberg $R_{\infty}\left(R_{\infty}=\right.$ $13.6 \mathrm{eV}$ ) sebagai satuan energi.

$$
-\frac{1}{r^{2}} \frac{d}{d r}\left(r^{2} \frac{d}{d r} \psi(r)\right)-\frac{2}{r} \psi(r)=\varepsilon \psi(r)
$$

Prinsip aksi stasioner dapat diterapkan untuk menurunkan bentuk diskret dari persamaan Schrödinger melalui pendekatan metode variasi[2,5,7].

$$
\Lambda=\int_{0}^{\infty} d r r^{2}\left[\psi^{* \prime}(r) \psi^{\prime}(r)-\psi^{*}(r)\left(\frac{2}{r}+\varepsilon\right) \psi(r)\right]
$$

Pada daerah asimtotik yaitu di $r=\infty$, fungsi gelombang dan turunannya menghilang secara eksponensial, sehingga agar dapat diselesaikan secara numerik, maka batas atas integral aksi harus diubah berhingga, $r=r_{c}$. Nilai $r_{c}$ dipilih sedemikian rupa sehingga fungsi gelombangnya mendekati nol di daerah asimtotik jauh.

$$
\Lambda=\int_{0}^{r_{c}} d r r^{2}\left[\psi^{*^{\prime}}(r) \psi^{\prime}(r)-\psi^{*}(r)\left(\frac{2}{r}+\varepsilon\right) \psi(r)\right]
$$


Dengan menggunakan prinsip daerah diskritisasi, maka integral aksi di atas dapat diperkirakan dengan memecah daerah integrasi menjadi nelem buah elemen kecil satu dimensi. Untuk daerah fisis $\left[0, r_{c}\right]$ seperti gambar berikut ini.

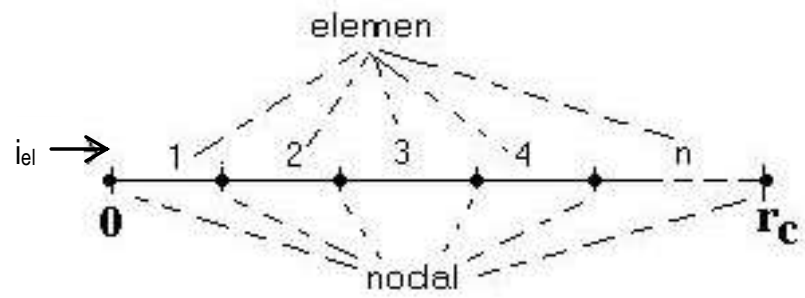

Gambar 2. Elemen di dalam daerah $\mathbf{0}, \mathbf{r}_{\mathbf{c}}$

Ukuran setiap elemen yaitu

$$
h=r_{c} / \text { nelem }
$$

Elemen ke $i_{e l}$

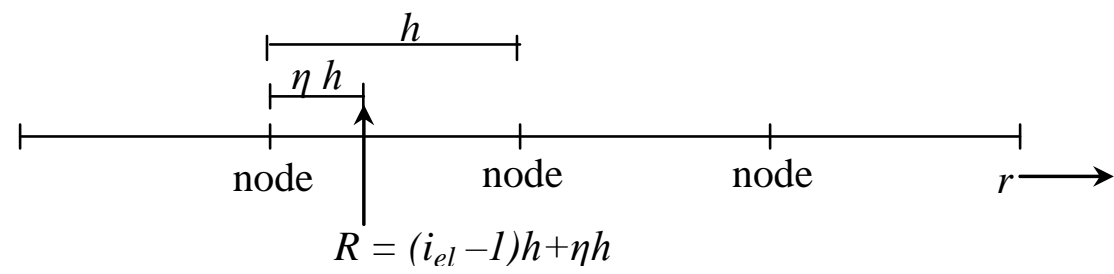

Gambar 3. Koordinat $r$ dalam elemen $i_{e l}$ (Desai, 1988)

Persamaan (12) dievaluasi dalam diskret dan untuk elemen ke-iel dapat dinyatakan

$$
\Lambda^{\left(i_{e l}\right)}=\int_{0}^{h} d r r^{2}\left[\psi^{* \prime}(r) \psi^{\prime}(r)-\psi^{*}(r)\left(\frac{2}{r}+\varepsilon\right) \psi(r)\right]
$$

Fungsi gelombang $\psi(r)$ pada persamaan ini dapat diinterpolasi dengan menggunakan interpolasi polinomial Lagrange. Interpolasi polinomial Lagrange yang digunakan memerlukan dua buah node $(n=2)$ untuk setiap elemen, seperti ditunjukkan pada dibawah ini.

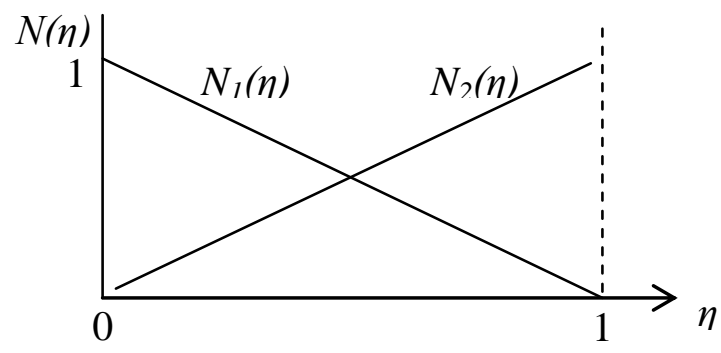

Gambar 4. Fungsi Lagrange untuk interpolasi linear-dua node tiap elemen (Brugioni, 1995) 
Fungsi gelombang $\psi(r)$ menjadi

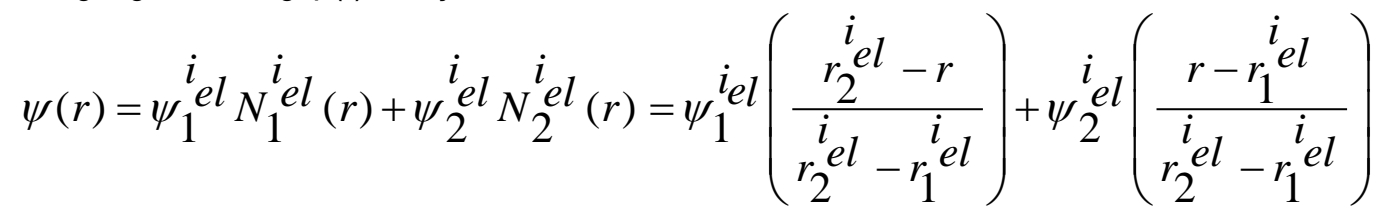

$r_{1}^{i}$ el merupakan titik awal dan $r_{2}^{i}$ el merupakan titik akhir. Pada Gambar 4 digunakan koordinat lokal $\eta$ dalam sebuah elemen yang mempunyai batas $[0,1]$ sehingga titik-titik nodal-nya

$$
\begin{aligned}
& r_{1}^{i_{e l}}=\left(i_{e l}-1\right) h \\
& r_{2}^{i_{e l}}=\left(i_{e l}-1\right) h+h
\end{aligned}
$$

Subsitusi titik-titik nodal (16) ke dalam fungsi gelombang (15) didapatkan

$$
\psi(r)=\psi_{1}^{i} e l(1-\eta)+\psi_{2}^{i} e l(\eta)
$$

Dari persamaan ini dapat diketahui bahwa fungsi interpolasi polinomial lokal pada titik awal $N_{1}(\eta)=1$ $\eta$ dan pada titik akhir $N_{2}(\eta)=\eta$. Turunan dari fungsi gelombang $\psi(r)$ adalah

$$
\frac{d \psi(r)}{d r}=\frac{1}{h}\left(-\psi_{1}^{i}{ }^{e l}+\psi_{2}^{i}{ }^{e l}\right)
$$

Faktor $h$ sebagai denominator muncul akibat transformasi koordinat dari $r$ menjadi $\eta$. Jika integral aksi pada sebuah elemen (persamaan 14) dituliskan dalam notasi matriks bujur sangkar $2 \times 2$, maka

$$
\begin{aligned}
\left.\Lambda^{(i} e l\right)= & \left.\int_{0}^{1} h^{3} d \eta\left[\left(i_{e l}-1\right)+\eta\right]^{2}\left\{\psi_{1} *^{\left(i_{e l}\right)}, \psi_{2} *^{(i} e l\right)\right\}\left[\frac{1}{h^{2}}\left(\begin{array}{cc}
1 & -1 \\
-1 & 1
\end{array}\right)\right. \\
& -\frac{2}{h\left(i_{e l}-1+\eta\right)}\left(\begin{array}{cc}
(1-\eta)^{2} & \left.\eta(1-\eta))-\varepsilon\left(\begin{array}{cc}
(1-\eta)^{2} & \eta(1-\eta) \\
\eta(1-\eta) & \eta^{2} \\
\eta(1-\eta) & \eta^{2}
\end{array}\right)\right]\left(\begin{array}{c}
\psi_{1}^{(i} e l \\
\left(^{\prime}{ }^{\prime}\right. \\
\psi_{2} e l
\end{array}\right)
\end{array}\right)
\end{aligned}
$$

Integral aksi di atas dapat dituliskan dalam bentuk

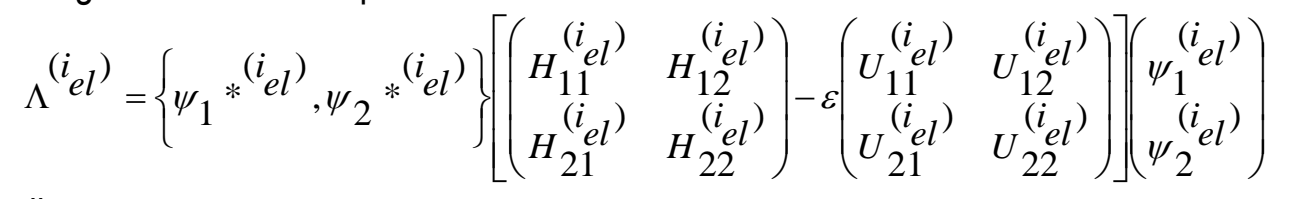

di mana

$$
\begin{aligned}
& H_{11}^{(n)}=h\left(\frac{1}{3}-n+n^{2}\right)+h^{2}\left(\frac{1}{2}-\frac{2}{3} n\right) \\
& H_{12}^{(n)}=H_{21}^{(n)}=h\left(-\frac{1}{3}+n-n^{2}\right)+h^{2}\left(\frac{1}{6}-\frac{1}{3} n\right) \\
& H_{22}^{(n)}=h\left(\frac{1}{3}-n+n^{2}\right)+h^{2}\left(\frac{1}{6}-\frac{2}{3} n\right)
\end{aligned}
$$




$$
\begin{aligned}
& U_{11}^{(n)}=h^{3}\left(\frac{1}{5}-\frac{1}{2} n+\frac{1}{3} n^{2}\right) \\
& U_{12}^{(n)}=U_{21}^{(n)}=h^{3}\left(\frac{1}{20}-\frac{1}{6} n+\frac{1}{6} n^{2}\right) \\
& U_{22}^{(n)}=h^{3}\left(\frac{1}{30}-\frac{1}{6} n+\frac{1}{3} n^{2}\right) \\
& \left(n=i_{e l}\right)
\end{aligned}
$$

Matriks global dapat dibentuk dengan menjumlahkan keseluruhan kontribusi integral aksi dari nelem buah elemen dengan syarat bahwa antar elemen kontinu. Dalam representasi matriks, kontinuitas antar elemen mengijinkan penjumlahan elemen matriks $H_{11}^{\left({ }^{(} e_{e l}\right)}$ pada $H_{22}^{\left({ }^{(i} e l\right.}{ }^{-1)}$, hal ini berlaku juga untuk matriks $U$. Untuk tiga elemen dapat digambarkan

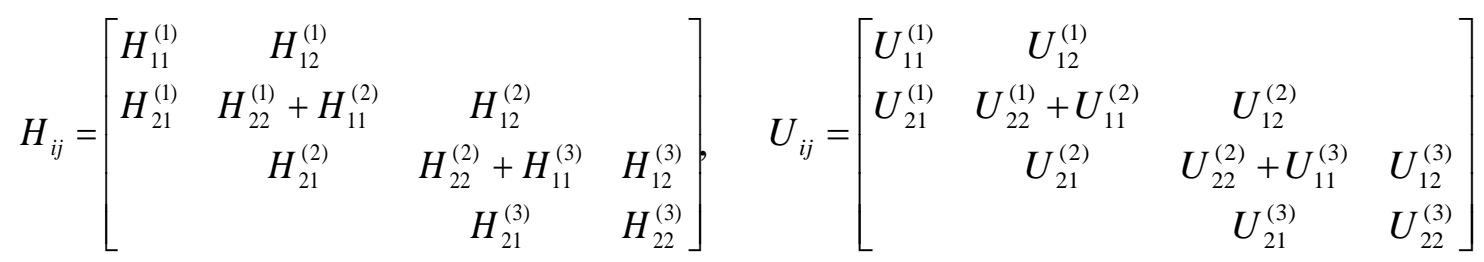

Gambar 5. Matriks global $H$ dan $U$ untuk tiga elemen

Dengan menggunakan indeks global sebagai pengganti indeks lokal maka node 1 dan 2 dalam elemen $i_{e /}$ dinyatakan kembali sebagai node $a=i_{e l}$ dan $a+1$. Demikian juga nilai nodal fungsi gelombang menjadi $\psi_{a}$ dan $\psi_{a+1}$. Total integral aksi untuk seluruh elemen

$$
\Lambda=\psi_{\alpha}^{*}\left[H_{\alpha \beta}-\varepsilon U_{\alpha \beta}\right] \psi_{\beta} ; \quad \alpha, \beta=1,2, \ldots, \text { nelem }+1,
$$

Matriks global $H$ dan $U$ memiliki dimensi (nelem+1) x (nelem+1).

Berdasarkan prinsip aksi stasioner dengan variasi integral aksi terhadap $\delta \psi_{\alpha}^{*}$ maka

$$
\delta \Lambda=0=\delta \psi_{\alpha}^{*} \frac{\delta \Lambda}{\delta \psi_{\alpha}^{*}}=\delta \psi_{\alpha}^{*}\left(H_{\alpha \beta}-\varepsilon U_{\alpha \beta}\right) \psi_{\beta}
$$

Karena variasi $\delta \psi_{\alpha}^{*}$ adalah sembarang maka bentuk umum persamaan nilai eigen

$$
H_{\alpha \beta}{ }_{\beta}-\varepsilon U_{\alpha \beta}{ }_{\beta}=0
$$

Jadi masalah nilai eigen akan dipecahkan sebagai masalah matriks melalui persamaan ini. Variabel yang dicari adalah nilai eigen $\varepsilon$ yang merupakan energi atom hidrogen dalam satuan Rydberg $R_{\infty}$.

\section{Analisa Perhitungan Tingkat-tingkat Energi Atom Hidrogen}

Dengan menggunakan kode komputer yang telah dibuat didapatkan nilai eigen yang menyatakan tingkat-tingkat energi atom hidrogen. Pemilihan kombinasi dari parameter-parameret input yang tepat menghasilkan tingkat-tingkat energi atom hidrogen dengan akurasi yang tinggi. Penulis menggunakan beberapa pilihan kombinasi parameter-parameter input yaitu batas atas integrasi $\left(r_{c}\right)$ 20-1000 ao dan jumlah elemen (nelem) 20-1000 elemen. 


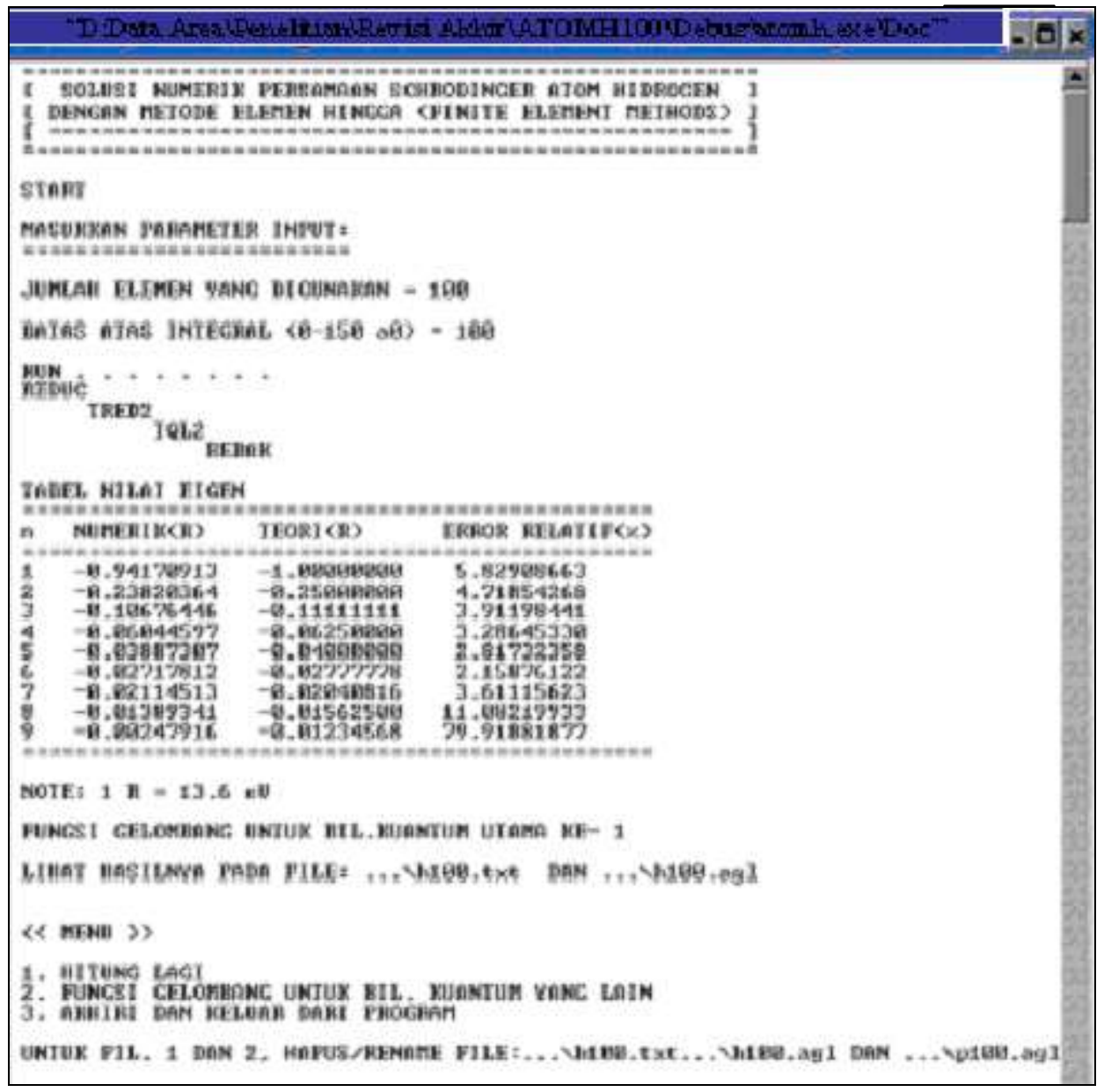

Gambar 6. Tampilan input - output kode komputer

Potensial Coulomb dalam integral aksi akan mendekati nol untuk $r$ yang besar sehingga mempunyai nilai eigen positif. Untuk atom hidrogen dimana elektron terikat pada inti (bound state) maka hanya nilai eigen negatif yang diijinkan. Nilai eigen negatif tersebut merupakan tingkat-tingkat energi atom hidrogen. Tingkat-tingkat energi atom hidrogen secara analitik dapat dirumuskan

$$
E_{n}=-\frac{1}{n^{2}} R_{\infty}
$$

dimana $n$ adalah bilangan kuantum utama. Hasil perhitungan tingkat-tingkat energi atom hidrogen secara numerik dan secara analitik dalam satuan Rydberg $R_{\infty}$ serta kesalahan relatifnya dapat diketahui secara langsung dengan kode komputer yang telah dibuat.

Analisa secara terpisah parameter input batas atas integrasi $r_{c}$ dilakukan dengan memberikan input batas atas integrasi 100 a o, 200 a0, 500 ao dan 1000 ao dengan jumlah elemen 1000. Dapat dilihat bahwa semakin besar batas atas integrasi maka semakin banyak tingkat-tingkat energi atom hidrogen yang dapat dihitung. Beberapa tingkat energi tertinggi mempunyai kesalahan relatif yang cukup besar. Hal ini disebabkan karena pengaruh syarat batas, dimana pada $r=r_{c}$ fungsi gelombang radial $\psi\left(r_{c}\right)$ diatur bernilai nol. 
Pengaruh jumlah elemen yang digunakan selama perhitungan (nelem) terhadap akurasi data yang akan dihasilkan dapat diketahui dengan menganalisis hasil perhitungan tingkat-tingkat energi atom hidrogen secara numerik untuk input $r_{c}=100$ ao dan nelem $=100,600$ dan 1000. Jika jumlah elemen yang digunakan dalam perhitungan semakin besar maka akurasi hasil perhitungan akan semakin baik. Hal ini dibuktikan dengan kesalahan relatif untuk masing-masing tingkat energi semakin kecil. Sebagai tambahan, jumlah elemen sangat berpengaruh terhadap lamanya running time dari kode komputer yang dibuat. Hal ini disebabkan karena jumlah elemen yang digunakan selama perhitungan menentukan besarnya orde matriks global yang harus ditangani. Semakin besar jumlah elemen maka orde matriks global juga semakin besar, akibatnya running time yang dibutuhkan semakin lama.

Batas atas integrasi dan jumlah elemen secara bersama-sama, dinyatakan dengan ukuran elemen (persamaan 13) juga mempengaruhi akurasi hasil perhitungan. Jika $h$ dalam perhitungan sama, maka akan mempunyai keadaan dasar (ground state) yang sama pula. Misalnya untuk $h=1$ yaitu pasangan batas atas integrasi $r_{c}$ dan jumlah elemen nelem $20 a_{0}: 20,100 a_{0}: 100$, dan $1000 a_{0}$ : 1000 mempunyai keadaan dasar yang tepat sama sebesar $-0.94170913 R_{\infty}$ dengan kesalahan relatif $5.82908663 \%$. Hal ini disebabkan karena 20 elemen pertama dalam perhitungan baik untuk 20 elemen, 100 elemen maupun 1000 elemen, mempunyai distribusi elemen yang sama pada seluruh daerah kritis yang berhubungan dengan keadaan dasar. Demikian juga untuk $h=1 / 6$ yaitu pasangan batas atas integrasi $r_{c}$ dan jumlah elemen nelem $20 a_{0}: 120$, dan $100 a_{0}: 600$ juga mempunyai keadaan dasar yang sama sebesar $-0.99772506 R_{\infty}$ dengan kesalahan relatif $0.22749426 \%$. Dari dua contoh nilai $h$ di atas, dapat dilihat bahwa $h=1 / 6$ mempunyai kesalahan relatif yang lebih kecil dibandingkan $h=1$. Hal ini berarti perhitungan keadaan dasar untuk $h=1 / 6$ mempunyai akurasi yang lebih baik. Berdasarkan nilai kesalahan relatif masing-masing tingkat energi untuk dua nilai $h$ tersebut dan nilai $h$ yang lain yaitu 1/2,1/5 dan 1/10 dapat disimpulkan bahwa semakin kecil ukuran elemen maka akurasi perhitungan secara numerik juga semakin baik.

Telaah atom hidrogen biasanya hanya melibatkan beberapa tingkat energi pertama yaitu yaitu keadaan dasar dan beberapa keadaan eksitasi (excitation states) pertama $(n<10)$. Pasangan input batas atas itegrasi $r_{c}$ dan jumlah elemen nelem $100 \mathrm{a}_{0}: 600,100 \mathrm{a}_{0}: 1000$, dan $200 \mathrm{a}_{0}: 1000$ menghasilkan eigen energi untuk enam tingkat pertama dengan kesalahan relatif kurang dari $1 \%$. Bahkan untuk pasangan input $200 a_{0}$ : 1000 sampai sembilan tingkat pertama mempunyai kesalahan relatif kurang dari $1 \%$. Jika ditinjau hanya pada lima tingkat energi pertama saja yaitu keadaan dasar dan empat keadaan eksitasi pertama, maka kombinasi parameter input batas atas integrasi $r_{c} 100 a_{0}$ dan jumlah elemen sebanyak 1000 merupakan pilihan realistis dan memberikan cukup informasi mengenai tingkat-tingkat energi atom hidrogen dengan akurasi yang baik dimana kesalahan relatifnya kurang dari $0,1 \%$.

$E_{1}=-0.99917211 R_{\infty}$ dengan kesalahan relatif $0,08278922 \%$,

$E_{2}=-0.24984445 R_{\infty}$ dengan kesalahan relatif $0,06222133 \%$,

$E_{3}=-0.11105532 R_{\infty}$ dengan kesalahan relatif $0,05021519 \%$,

$E_{4}=-0.06247405 R_{\infty}$ dengan kesalahan relatif $0,04151635 \%$,

$E_{5}=-0.03998598 R_{\infty}$ dengan kesalahan relatif $0,03504057 \%$.

Secara umum, parameter input yang digunakan selama perhitungan dapat diatur sedemikian hingga untuk mendapatkan tingkat-tingkat energi atom hidrogen dengan akurasi yang tinggi. Tentunya, dengan tetap memperhatikan spesifikasi dari komputer yang digunakan. 


\section{Analisa Fungsi Gelombang Radial dan Probabilitas Radial}

Dari perhitungan numerik yang telah dilakukan, juga didapatkan fungsi eigen yang menyatakan fungsi gelombang radial atom hidrogen untuk keadaan $n s$. Secara analitik, fungsi gelombang radial atom hidrogen untuk tiga keadaan ns yang pertama dalam satuan atomik a.u dapat dirumuskan (Brasden \& Joachain, 1995).

$$
\begin{aligned}
& \psi_{10}(r)=2 \exp (-r) \\
& \psi_{20}(r)=2(1 / 2)^{3 / 2}(1-r / 2) \exp (-r / 2) \\
& \psi_{30}(r)=2(1 / 3)^{3 / 2}\left(1-2 r / 3+2 r^{2} / 27\right) \exp (-r / 3)
\end{aligned}
$$

Visualisasi fungsi gelombang radial atom hidrogen secara numerik dan secara analitik untuk tiga keadaan pertama ( $1 s, 2 s$ dan $3 s$ ) untuk pilihan kombinasi parameter input $R c=100 a_{0}$ dan nelem 100 ditunjukkan pada Gambar 7 sampai Gambar 9.

Kesesuaian antara fungsi gelombang radial atom hidrogen secara numerik dan secara analitik dapat diketahui dengan membandingkan secara langsung melalui visualisasi grafik.

Seperti halnya dalam analisis tingkat-tingkat energi atom hidrogen, batas atas integrasi $r_{c}$ dan jumlah elemen nelem yang digunakan selama perhitungan sangat mempengaruhi akurasi fungsi gelombang radial yang dihasilkan. Fungsi gelombang radial atom hidrogen $\psi(r)$ tidak sama dengan nol pada $r=0$. Begitu juga dengan turunannya $d(\psi(r)) / d r \neq 0$ pada $r=0$. Hal ini disebabkan karena energi potensial untuk atom hidrogen bernilai tak hingga pada titik $r=0$. Untuk nilai-nilai $n$ yang besar (keadaan-keadaan eksitasi), fungsi gelombang radial dipengaruhi oleh pemberian syarat batas dimana pada $r=r_{c}$ fungsi gelombang radial diatur bernilai nol, $\psi\left(r=r_{c}\right)=0$. Secara umum, untuk $n$ yang besar tingkat kesesuaian antara fungsi gelombang radial atom hidrogen secara numerik dan secara analitik lebih kecil. Misalnya untuk batas integrasi $20 \mathrm{a}_{0}$, terlihat bahwa $\psi_{30}(r)$ mempunyai simpangan yang lebih besar jila dibandingkan dengan $\psi_{20}(r)$ dan $\psi_{20}(r)$ juga mempunyai simpangan yang lebih besar bila dibandingkan dengan $\psi_{10}(r)$. Berdasarkan visualisasi fungsi gelombang radial atom hidrogen untuk beberapa pilihan kombinasi parameter input, semakin besar batas atas integrasi yang diberikan maka semakin baik kesesuaian antara fungsi gelombang radial atom hidrogen secara numerik dan secara analitik. Hal ini terutama terlihat untuk keadaankeadaan eksitasi. Jumlah elemen yang digunakan juga mempengaruhi akurasi fungsi gelombang radial atom hidrogen yang dihasilkan dimana semakin banyak jumlah elemen yang digunakan maka semakin baik kesesuaian antara fungsi gelombang radial atom hidrogen secara numerik dan secara analitik. Hal ini berlaku baik untuk keadaan dasar maupun keadaan-keadaan eksitasi.

Kita telah menghitung fungsi gelombang radial atom hidrogen $\psi(r)$ dimana kuadrat dari

fungsi gelombang radial $|\psi(r)|^{2}$ menyatakan kerapatan elektron sebagai fungsi dari koordinat radial r. Probabilitas per satuan panjang bahwa elektron dapat ditemukan pada jarak $r$ dari inti disebut fungsi distribusi radial (Brasden \& Joachain, 1995).

$$
D_{n s}(r)=r^{2}\left|\psi_{n s}(r)\right|^{2}
$$




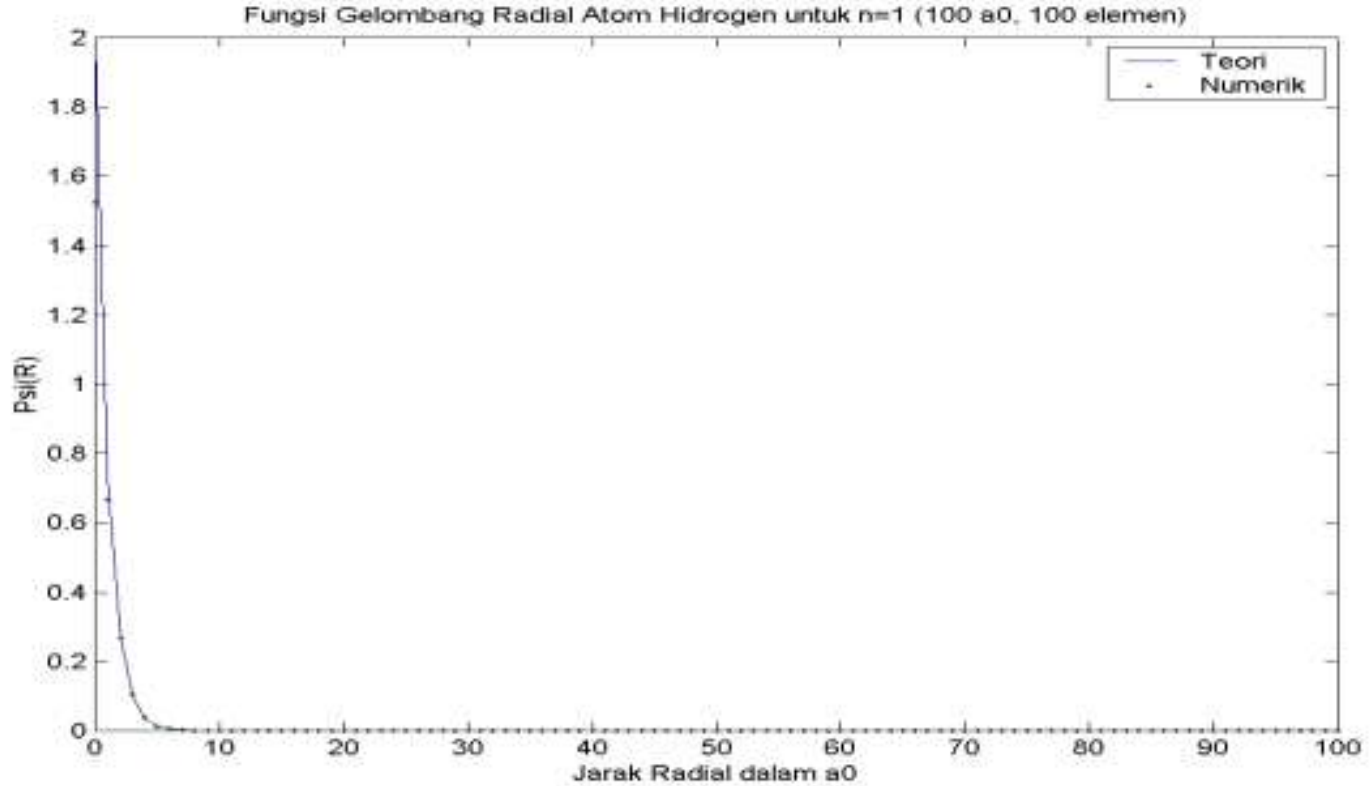

Gambar 7. Fungsi Gelombang Radial Atom Hidrogen untuk $n=1$ Batas Integrasi 100 dan Jumlah Elemen 100

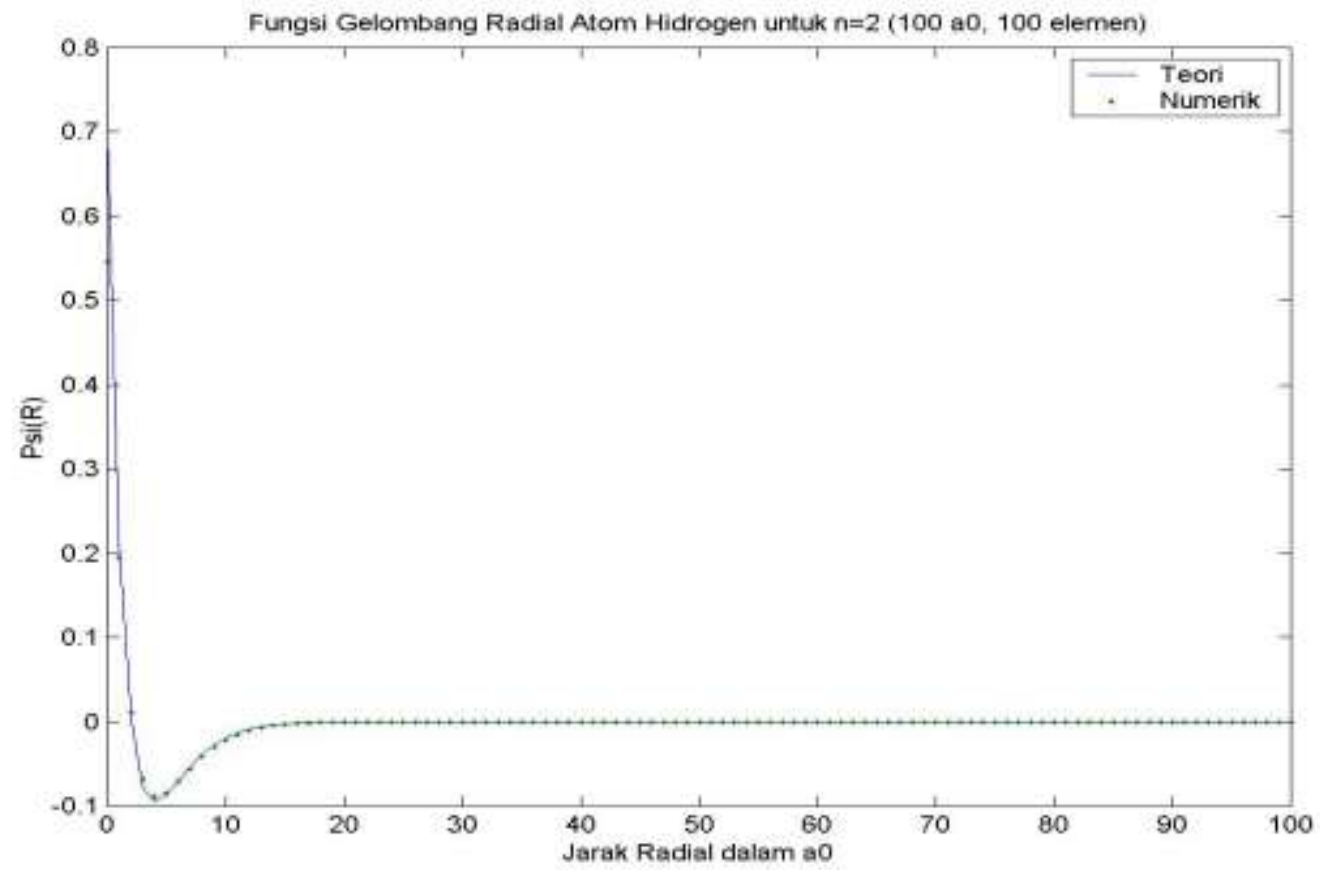

Gambar 8. Fungsi Gelombang Radial Atom Hidrogen untuk $n=2$ Batas Integrasi 100 dan Jumlah Elemen 100 


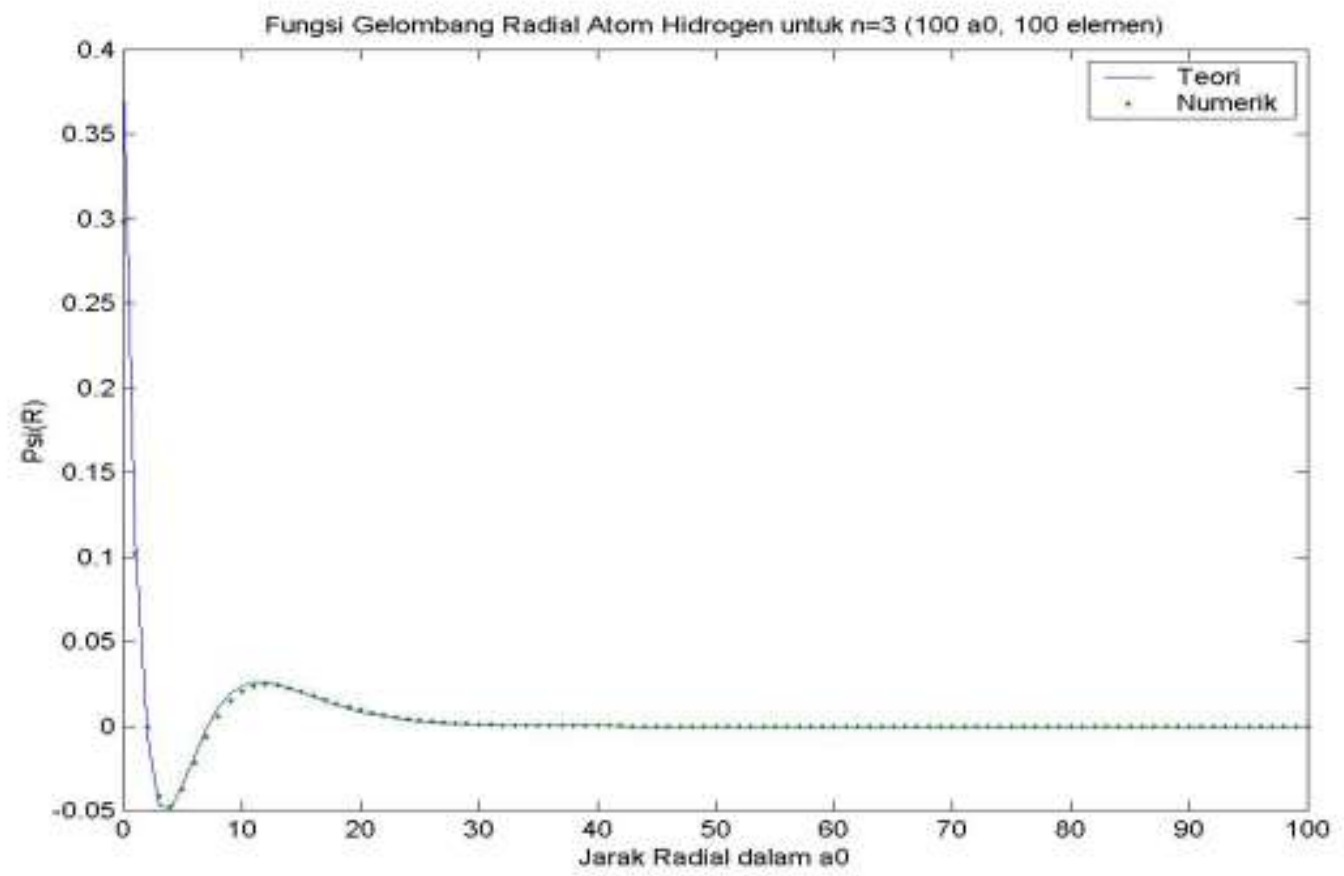

Gambar 9. Fungsi Gelombang Radial Atom Hidrogen untuk $n=3$ Batas Integrasi 100 dan Jumlah Elemen 100

Dari visualisasi fungsi distribusi radial dapat diketahui bahwa probabilitas terbesar untuk menemukan elektron pada jarak tertentu $r$ sebanding dengan $n^{2}$. Nilai maksimum fungsi distribusi radial semakin jauh dari inti jika $n$ semakin besar.

Analisis kesesuaian antara fungsi distribusi radial secara numerik dan analitik tidak dibahas dengan alasan fungsi distribusi radial merupakan kuadrat dari fungsi gelombang radial. Artinya jika fungsi gelombang radial secara numerik mempunyai kesesuaian yang baik dengan hasil secara analitik maka fungsi distribusi radial secara numerik juga mempunyai kesesuaian yang baik dengan hasil analitik.

\section{KESIMPULAN}

Telaah problem atom hidrogen secara numerik dengan menggunakan FEM menghasilkan tingkattingkat energi dan fungsi gelombang radial atom hidrogen. Hasil perhitungan yang didapatkan sangat bergantung pada parameter input yang digunakan. Batas integrasi dari integral aksi persamaan Schrödinger dan jumlah elemen, baik secara terpisah maupun secara bersama sama, sangat mempengaruhi hasil perhitungan numerik. Pilihan kombinasi batas atas integrasi $100 \mathrm{a}_{0}$ dengan jumlah elemen sebanyak 1000 memberikan tingkat-tingkat energi atom hidrogen dengan akurasi yang baik. Untuk lima tingkat energi pertama yaitu $E_{1}=-0.99917211 R_{\infty}, E_{2}=-0.24984445 R_{\infty}, E_{3}=-$ $0.11105532 R_{\infty}, E_{4}=-0.06247405 R_{\infty}$ dan $E_{5}=-0.03998598 R_{\infty}$ dimana $R_{\infty}=13.6 \mathrm{eV}$. Masingmasing tingkat energi tersebut mempunyai kesalahan relatif kurang dari $0.1 \%$ terhadap hasil analitik. 


\section{REFERENSI}

Brasden, B. H. \& Joachain, C. J. (1995). Physics of atoms and molecules. New York: John Wiley \& Sons, Inc.

Brugioni, J. P. (1995). Finite element method in quantum mechanics.

http://www.science.gmu.edu/ jbrugion/RTF/qm1.htm. Diambil 19 Oktober 2004.

Gasiorowicz, S. (1995). Quantum physics. USA: John Wiley \& Sons, Inc.

Mohan, L. R. (2002). Finite element and boundary element applications in quantum mechanics. New York: Oxford University Press.

Nikishkov, G. P. (2004). Introduction to the finite elemen method. Lecture Note. University of Aizau, Japan.

Thankappan, V. K. (1985). Quantum mechanics. New Delhi: Wiley Eastern Limited. 